\title{
29. SYNDEPOSITIONAL TECTONICS ALONG THE MIDDLE AMERICA TRENCH, WITH SPECIAL REFERENCE TO FORAMINIFERAL BATHYMETRY: DEEP SEA DRILLING PROJECT LEG 66, OFFSHORE MEXICO-GEOLOGICAL PROCESSES ALONG AN ACTIVE MARGIN ${ }^{1}$
}

\author{
Arif Butt, Geologisches und Paläontologisches Institut der Universität Tübingen, \\ 74 Tübingen, Federal Republic of Germany
}

\begin{abstract}
Biostratigraphic data of the Middle America Trench indicate that the sediments decrease in age in the direction of the trench axis. Upper and middle slope sites (493 and 489) contain the oldest sediment (early Miocene above the basement), whereas sites in the accretionary and transitional zones contain middle Miocene through Pleistocene. This diachronous stratigraphic trend along the inner wall suggests accretion. Geophysical sedimentological and paleontologic evidence reveals a general uplift of the continental plate. The accretionary zone sites $(488,492,491)$ and transitional zone site (490) reveal uplift of 500 to $200 \mathrm{~m} / \mathrm{m}$.y., whereas the sites at the continental plate indicate uplift of 100 to $80 \mathrm{~m} / \mathrm{m} . \mathrm{y}$. These sediments were originally deposited in the trench environments and later uplifted. All the sites in the accretionary and transitional zones consist of three zones (A-C) with respect to abundance and preservation of planktonic foraminifers. Zone $\mathrm{A}$ is barren of calcareous fossils and was probably deposited below the CCD (calcite compensation depth) at 4000 to 5000 meters depth. Zone B contains rare and poorly preserved planktonic foraminifers. The facies indicate deposition near the CCD at a depth of perhaps 3000 to 4000 meters. Zone C contains abundant and well-preserved planktonic foraminifers, suggesting deposition above the CCD. Benthic foraminifers correspond to the present depth along the inner slope sites. Zones A to C suggest a marked uplift of the sites relative to the CCD.

Some planktonic foraminifers in the basal core of Site 487 indicate a late Miocene data for the basaltic basement.

Sites 486, 487, and 488 lie below the present CCD. However, the Quaternary cores contain well-preserved, smallsized planktonic foraminifers. They were transported by turbidity currents and rapidly buried with sand particles. In contrast to small-sized species the larger solution-resistant species such as Globorotalia menardii are poorly preserved. They represent productivity of the overlying water mass and slow deposition through the CCD. Furthermore, these foraminifers remain exposed for a longer time at the interface at the seafloor.
\end{abstract}

\section{INTRODUCTION}

During Leg 66, eight sites (Figs. 1 and 2) were drilled along the Oaxaca Transect, offshore Mexico. The main objective of this cruise was to study the tectonic framework of the Middle America Trench, in particular the dynamics of the accretionary zone and the subduction process. Another objective was to make a detailed analysis of the paleoenvironments of the accreted sediments.

Convergence between the Cocos and North American plates has been occurring for the last $100 \mathrm{~m}$.y., whereas the episodes of subduction since the Neogene occurred at a rate of $8 \mathrm{~cm} / \mathrm{y}$. (Larson and Chase, 1970; Molnar and Sykes, 1969; Schilt and Truchan, 1976). Excellent bathymetric and seismic survey data are documented by Shipley et al. (1979, in press). In contrast to the offshore Guatemala margin (Leg 67), the margin along Oaxaca is truncated due to an oblique subduction phenomenon. The Middle America Trench is characterized by a narrow shelf, steep slope, and the absence of a forearc basin. Seismic data of Shipley et al. (in press) indicate landward-dipping reflectors, suggesting a general uplift along the lower and middle slope areas. In contrast to other Pacific trenches rimmed along the continents, the Middle America Trench is shallower and therefore was considered favorable for drilling.

\footnotetext{
${ }^{1}$ Initial Reports of the Deep Sea Drilling Project, Volume 66
}

Gassy frozen sediments were recovered at Sites 490 , 491, and 492. At all the sites in the accretionary and transitional zones, gas hydrates (mainly methane) were recovered, as the seismic data had predicted (Shipley et al., 1979).

Along the coast, mainly Precambrian and Paleozoic crystalline rocks are exposed. They have undergone several phases of metamorphism. In some places Triassic miogeosynclinal calcareous facies are also exposed. During the Cretaceous to Eocene, volcanic rocks such as andesites, rhyolites, and basalt were intruded into the crystalline basement (Alvarez, 1949; Guzman, 1950; de Cserna, 1965; and Shipley et al., in press), suggesting the existence of an ancient volcanic arc and forearc basin that was probably truncated during the Neogene subduction phases.

\section{FACIES DISTRIBUTION}

Site 487 (outer slope) is located at the oceanic plate, Site 486 in the trench basin, Sites 489 and 493 (upper slope) at the continent plates, whereas Sites 491, 492, 488 and 490 are in the accretionary and transitional zones (middle and lower slope) (Figs. 1 and 2). The planktonic foraminifer species at all the sites of Leg 66 reveal tropical to subtropical assemblages and are as follows. Globorotalia truncatulinoides: a Pliocene-Pleistocene boundary marker is absent in the vicinity of Leg 66 sites. In general, the planktonic foraminifers are rare. They were either dissolved below the CCD or diluted owing to the high rate of terrigenous influx. Sediments 


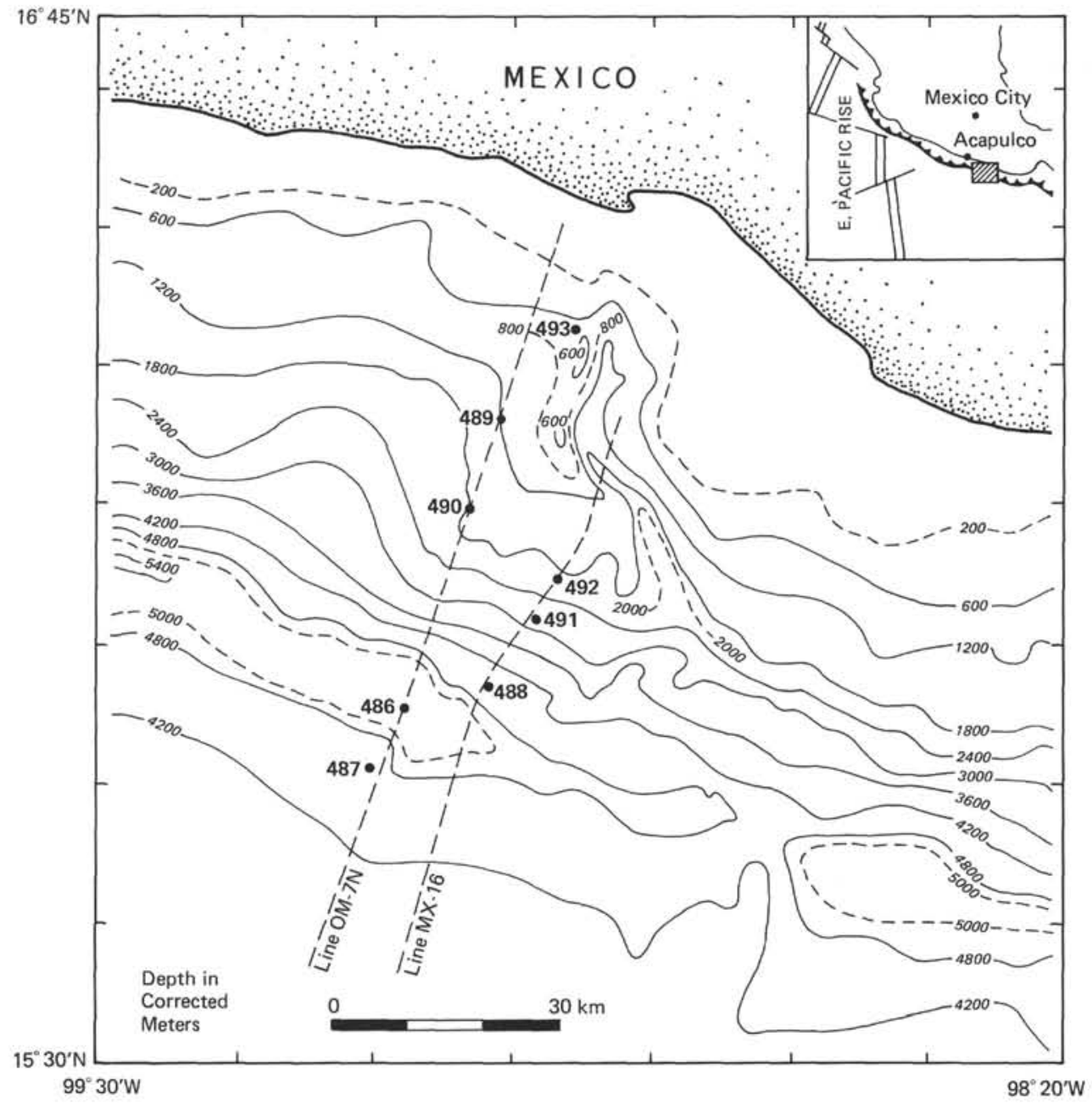

Figure 1. Location of Leg 66 sites.

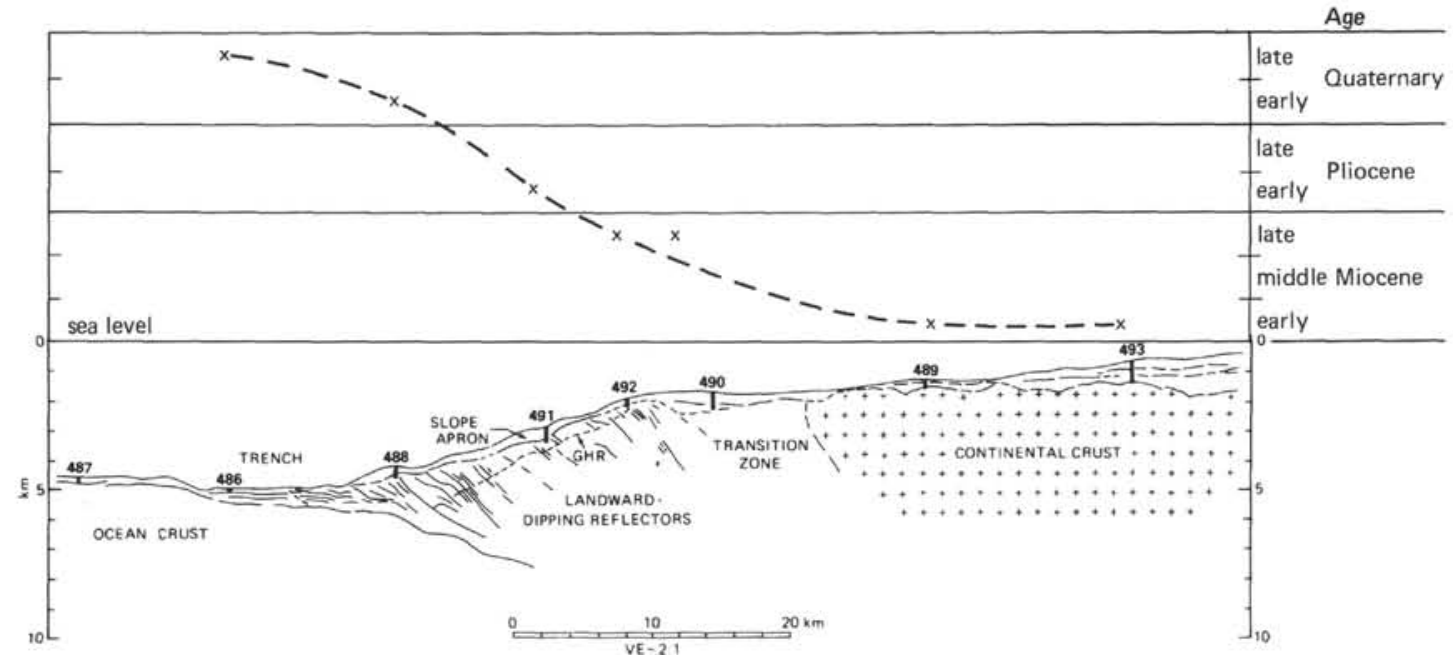

Figure 2. Location of Leg 66 sites along Oaxaca Transect. Dotted line indicates the diachronous progression of the sediments toward the trench axis. 
in the cores display mainly hemipelagic facies (greenish gray silts), and the upper few Quaternary cores contain abundant glauconite along the inner slope. The trench basin is filled with medium to coarse sand transported by the turbidity currents via submarine canyons. In contrast to the inner slope and trench basin, the oceanic realm (outer slope-abyssal plain) consists of pelagic and hemipelagic facies.

It is noteworthy that in all sedimentary cores from Leg 66 calcium carbonate is absent or low (1-9\%). True pelagic layers are absent, and Bouma's ideal turbidite sequences are difficult to recognize. Nevertheless, accumulation of terrigenous sand in the Middle America Trench basin may represent a modern site of flysch sedimentation, analogous to the eastern Alpine flysch trench sediments (such as Cretaceous "Reiselberger Sandstein" and "Bleicherhorn-Serie"). Furthermore: do the accretionary zone sediments correspond to "embryonic" nappes-a term used in the ancient geosynclines?

\section{BIOSTRATIGRAPHY AND PALEOENVIRONMENTS}

\section{Outer Wall and Trench Basin}

Site 487 is located on ocean crust at a water depth of 4774 meters (Figs. 1 and 2). At this site, 171 meters of thick upper Miocene to Quaternary sedimentary section was penetrated (Fig. 3). Hole 487 cores (1-20) display pelagic and hemipelagic facies, Cores 1 to 13 contain dark greenish silty facies, and 14 through 19 red brown clay overlying ocean crust. In general, the sediments contain rare foraminifers, whereas the brown clay is practically barren of calcareous fossils; fish teeth, sponge spicules, and radiolarians occur. In Core 19, however well-preserved planktonic and benthic foraminifers were recovered.

Although we cannot apply foraminiferal biostratigraphy, because of the rare occurrence of planktonic species, Cores 1 to 8 do contain a few Quaternary species such as Globorotalia tumida, G. menardii, Neogloboquadrina, Globigerinoides trilobus, G. ruber, and Orbulina universa. In Cores 19 and 20 some planktonic species are recovered (see site chapter). They indicate a late Miocene age for the ocean crust.

Benthic foraminifers indicate reworked lower slope faunal assemblage. They were probably displaced by the turbidity currents and redeposited at present abyssal depth. They include Melonis pompilioides, Gyroidina aff. soldanii, Pullenia bulloides, Oridorsalis umbonatus, Cibicidoides, and Pseudonodosaria.

Rare occurrence of planktonic foraminifers in the Quaternary hemipelagic sediments and total absence of calcareous microfossils in the Pliocene and Miocene brown clays indicate that the site is located below the $\mathrm{CCD}$, but the occurrence of some well-preserved calcareous foraminifers in Cores 19 and 20 suggests that perhaps the site was located above the CCD and later subsided below it. Rare occurrence of planktonic foraminifers with some benthic foraminifers during the Quaternary indicates that these calcareous fossils escaped dissolution by the rapid burial below the CCD by tur- bidity currents. The rate of sedimentation continuously increased from the Miocene to the Quaternary. Upward grading of pelagic facies (Miocene to Pliocene) to hemipelagic facies (Quaternary) indicates a change in the depositional environment. It may also suggest a landward movement of the oceanic plate and sedimentologic control of the trench environment. Large-sized species such as Globorotalia menardii and G. tumida are poorly preserved, and in certain cases only the keels of the genus are recovered; small-sized species such as Globigerinoides ruber, however, are well preserved. This confirms that the larger species slowly settled on the seafloor through the CCD whereas the small species are well preserved thanks to rapid burial by the turbidity currents.

Site 486 is located in the trench basin (Figs. 1 and 2). Two holes, 486 and $486 \mathrm{~A}$, penetrate trench fill sediments at water depths of 5152 and 5141 meters respectively. In the two holes fine to medium clay sand and very coarse sand of Quaternary age were recovered (Fig. 3). Cores 2 to 5 in Hole 486 and 1 to 3 in Hole 486 A contain scarce foraminifers. They are poorly preserved and are not useful for biostratigraphic analysis. Planktonic species include Globigerinoides trilobus, G. ruber, and G. sacculifer. Large-sized species such as Globorotalia menardii are extremely rare and very poorly preserved. In most cases only the keels are observed. Some reworked Miocene species are also recovered (see site chapter). The assemblage also includes relatively abundant benthic foraminifers. They are shelf-derived and indicate a near-shore environment for the sediment source. The members include Quinqueloculina, Eggerella, Bolivina (common), Bulimina, Anomalina, Gavelinella, Nonion, Hoeglundina, Cassidulina, and Uvigerina. Other microfossils include ostracods, gastropods, pelecypods, echinoid spines, fish teeth, and plant fragments and seeds.

The trench basin consists mainly of terrigenous facies and reworked biogenic components. The facies indicate a near-shore deltaic environment as the source, although some shelf edge and upper slope species are also encountered. The trench fill sediment indicates turbidity current environment. The material was probably transported via submarine canyons along the inner slope. Rare and poorly preserved occurrence of the large-sized planktonic foraminifers, such as relicts of keels, suggests that the basin at present is located below the CCD, whereas occurrence of the small-sized well-preserved foraminifers suggests they were redeposited below the CCD by the turbidity currents and hence escaped dissolution.

\section{Inner Wall of the Trench (Continental Slope)}

Site 488 is located at the toe of the landward slope at a water depth of 4265 meters (Figs. 1 and 2). A nearly 482-meter sedimentary section of middle to late Quaternary age was recovered (Fig. 3). Cores 1 to 46 exhibit dark greenish gray to olive gray silty mud facies showing laminated horizons, and in the basal unit coarse sand is interbedded.

Foraminifers are generally rare, and samples consist mainly of terrigenous material as well as plant fragments, molluscan debris, and pyritized tubelike bur- 

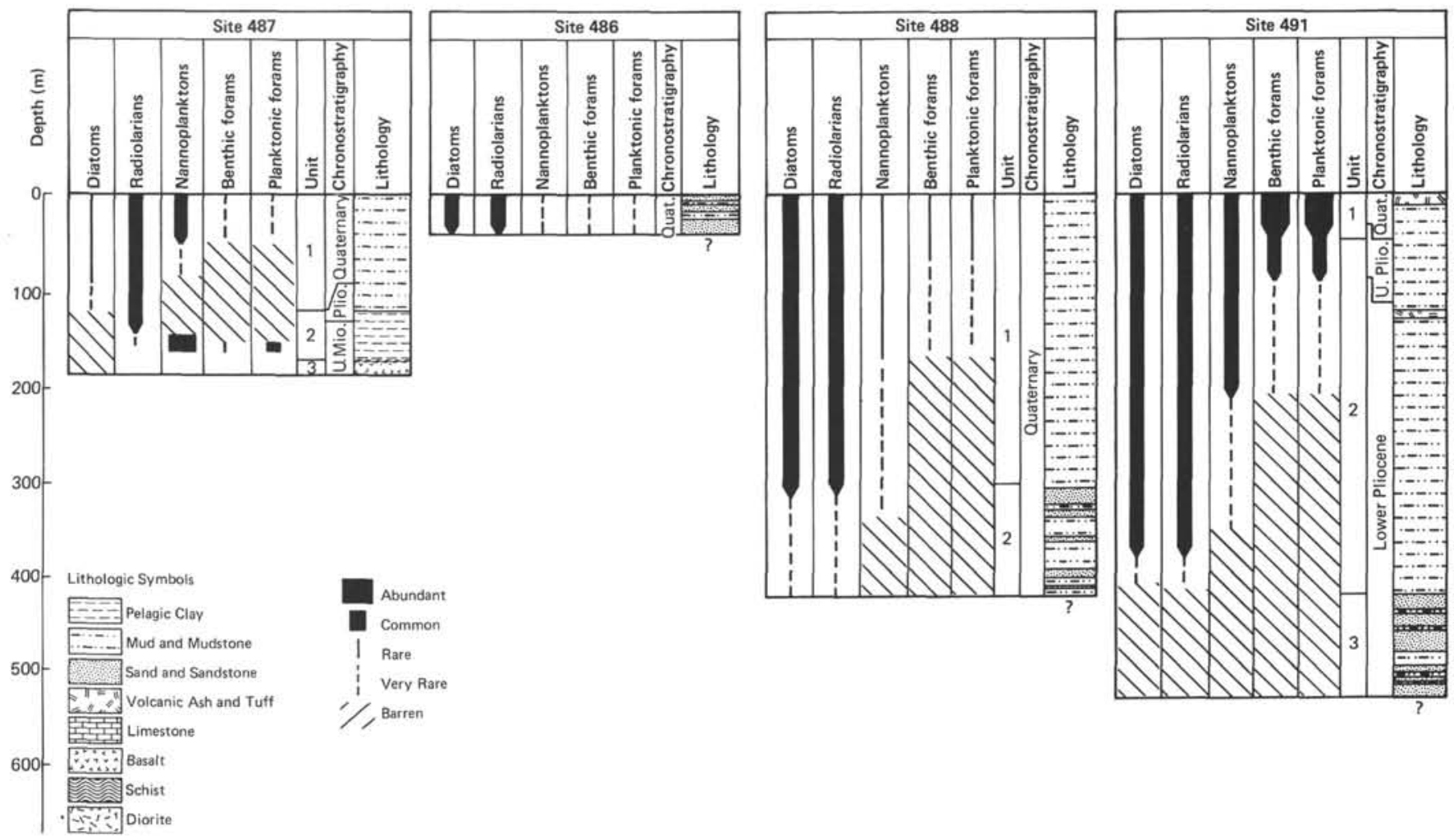

Figure 3. Distribution of microfossils at Leg 66 Mid America Trench sites.

rows. Rare planktonic foraminifers were recovered in Cores 1 to 25 . They indicate Quaternary age for the sediment. Cores 26 to 46 are practically barren. Planktonic species include Neogloboquadrina dutertrei, Globorotalia tumida, G. menardii, Globigerinoides ruber, G. trilobus, Globigerina bulloides, and G. falconensis. Small, thin-walled benthic foraminifers occur in Cores 1 to 42 and represent a redeposited assemblage. The members of the assemblage are Bolivina, Gavelinella, Cassidulina, Gyroidina, Eponides, Nonion, Polymorphina, and miliolids. The benthic assemblage also includes Oridorsalis umbonatus, Melonispompilioides, Cibicidoides, Uvigerina peregrina, $U$. proboscidea, $U$. aff. senticosa. They indicate upper and middle slope environments. At Site 488 the benthic foraminifers are probably redeposited from shelf and upper and middle slope.

At present the site is located below the CCD. Solutionresistant species such as Globorotalia menardii and $G$. tumida are often partially dissolved, and in many cases only the keels are recovered. In contrast to the large species, the small species such as Globigerinoides ruber are well preserved, suggesting rapid burial below the CCD. The sedimentation rate at Site 488 is very high $\left(420 \mathrm{~m} / \mathrm{m} . \mathrm{y}\right.$.). Absence of in situ ${ }^{2}$ benthic foraminifers apparently indicates a high terrigenous influx as well as stagnation. Lithology and microfossils at Site 488 display similarity with the trench fill sediments, suggesting

\footnotetext{
${ }^{2}$ Only a few small-sized sponges survived in the Quaternary sediments. Their occurrence suggests that these animals are the most resistant to a hostile environment.
}

that the basal part with the interbedded coarse sands was probably deposited in the ancient trench basin at a water depth of 5000 meters or greater. Compared with the present water depth of the site, the uplift rate averages between 400 and $500 \mathrm{~m} / \mathrm{m}$.y. (Figs. 4 and 5).

Site 491 is located on the lower slope (Figs. 1 and 2) at a water depth of 2883 meters. At this site, a 542-meter sedimentary section (olive green grayish silty mud) (Cores 1-59) of Pliocene to Quaternary age was recovered (Fig. 3). In the basal part the coarse sands are interbedded. Planktonic foraminifers are few to common in Cores 1 and 3, rare to very rare in Cores 4 to 6 , and absent in Cores 7 to 59 . The Quaternary assemblage contain well-preserved and partially corroded planktonic foraminifers. They include (Cores 1-3) Globorotalia tumida, G. flexuosa, Globigerinoides ruber, $G$. sacculifer, G. trilobus, Neogloboquadrina dutertrei, and Orbulina universa. No Pliocene index species are recorded, but in Cores 4 and 5 the occurrence of $\mathrm{NeO}$ globoquadrina acostaensis and Neogloboquadrina humerosa may indicate late Pliocene date for the cores. Absence and/or poor preservation (Cores 4-59) of the foraminifers suggest that the Pliocene part of the section was deposited below the CCD. The basal sediments at Site 491 consists of the coarse interbedded sand layers. the Pliocene barren facies was probably deposited in the trench basin at a depth between 4000 to 5000 meters and later uplifted to the present water depth at the rate of $423 \mathrm{~m} / \mathrm{m} . \mathrm{y}$. through the CCD. Poor preservation of the upper Pliocene planktonic foraminifers indicates that Site 491 was located near the CCD during the late Pliocene, whereas relative poor preservation of 

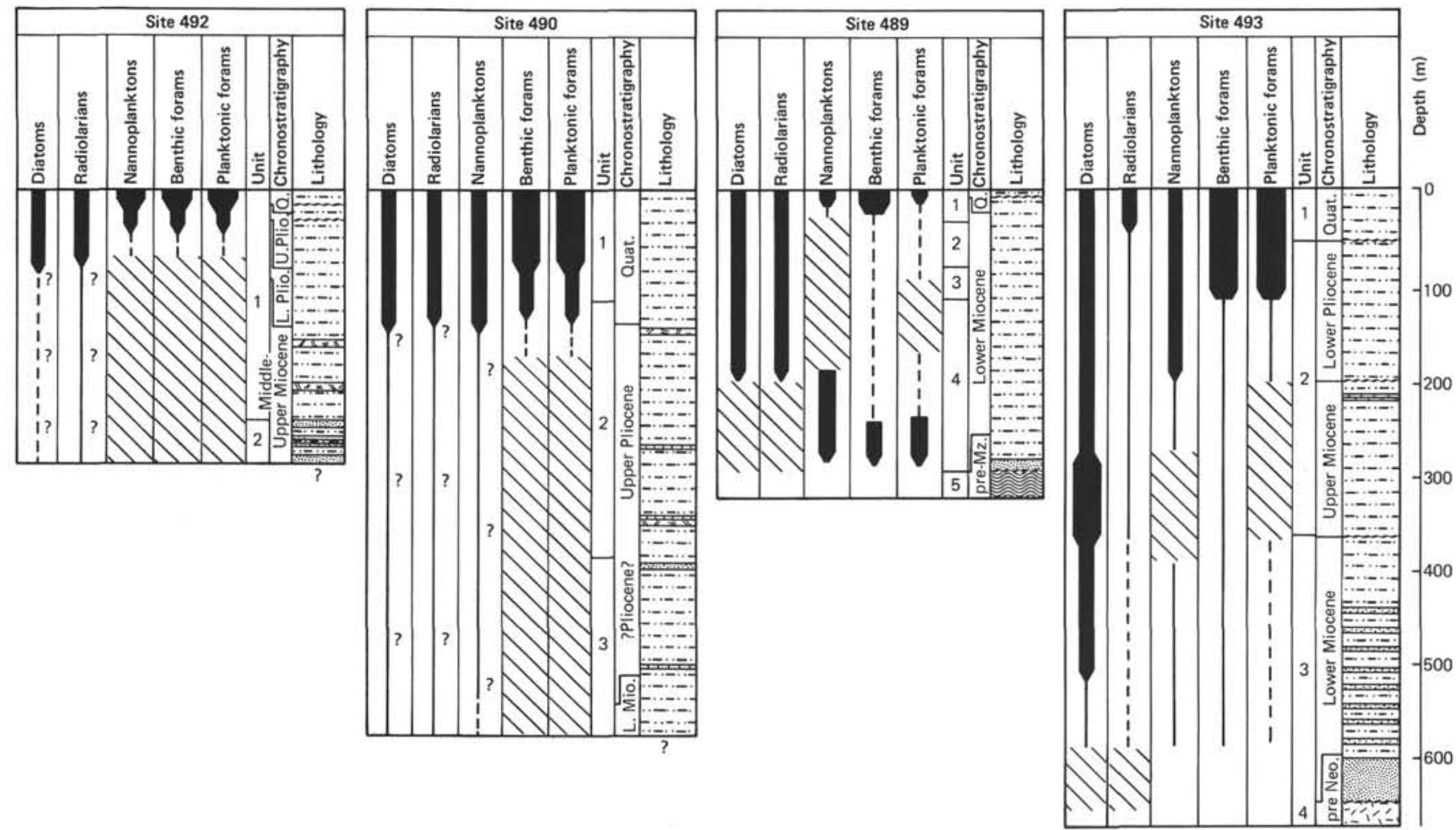

Figure 3. (Continued).
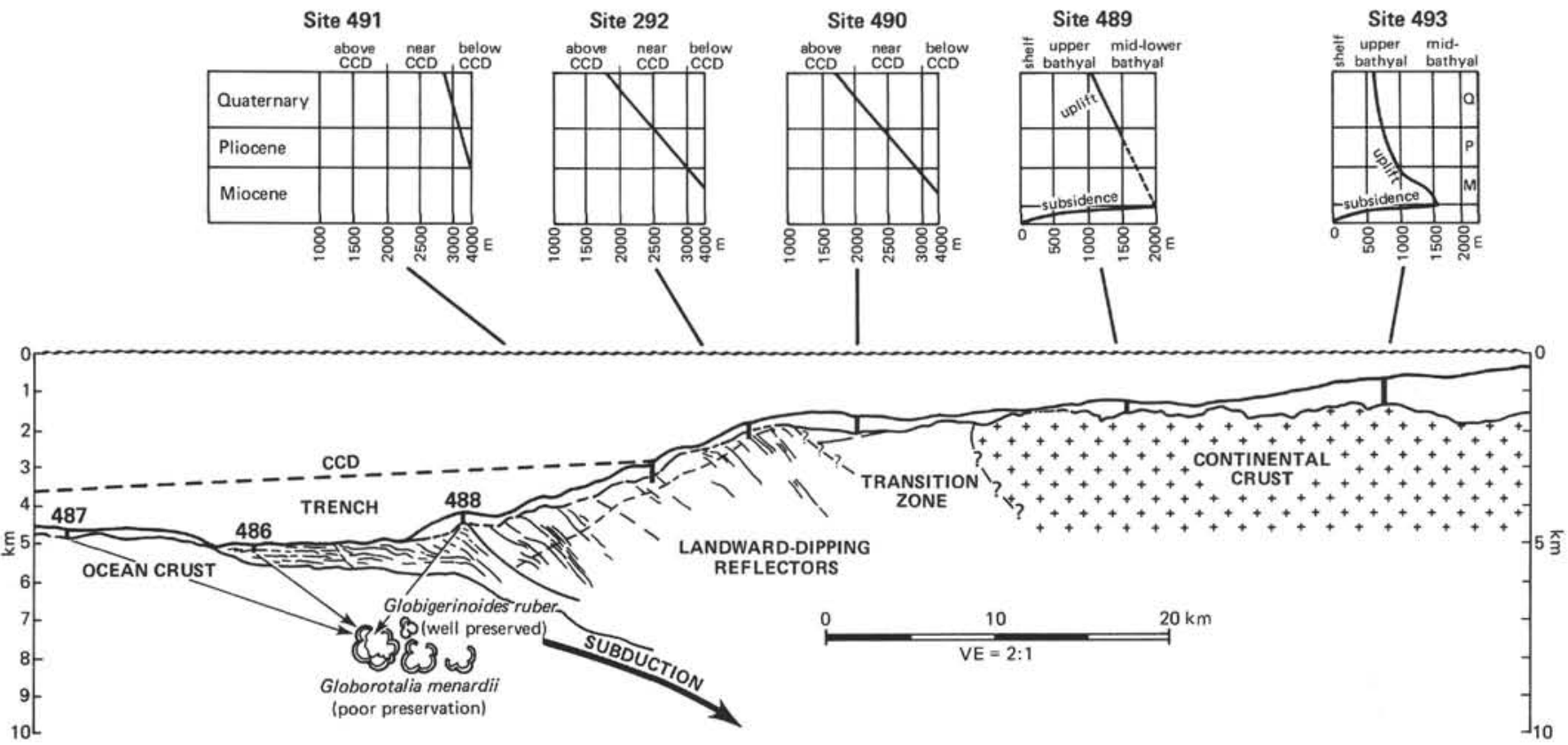

Figure 4. Paleobathymetric curves showing uplift and subsidence relative to the CCD.

the Quaternary planktonic foraminifers indicates that the site is located below the foraminiferal lysocline or local excursion of the CCD. The benthic community corresponds to lower bathyal present-day water depth. The members include Melonis pompilioides, Planulina wuellerstorfi, Hoeglundina elegans, Uvigerina probo- scidea, U. hispida, Bulimina striata, and Pyrgo depressa (Figs. 4 and 5).

Site 492 is located in the midslope area at a water depth of 1935 meters (Figs. 1 and 2). The sedimentary section consists of 279 meters of middle Miocene to Quaternary hemipelagic sediments (Fig. 3). The cores 
w
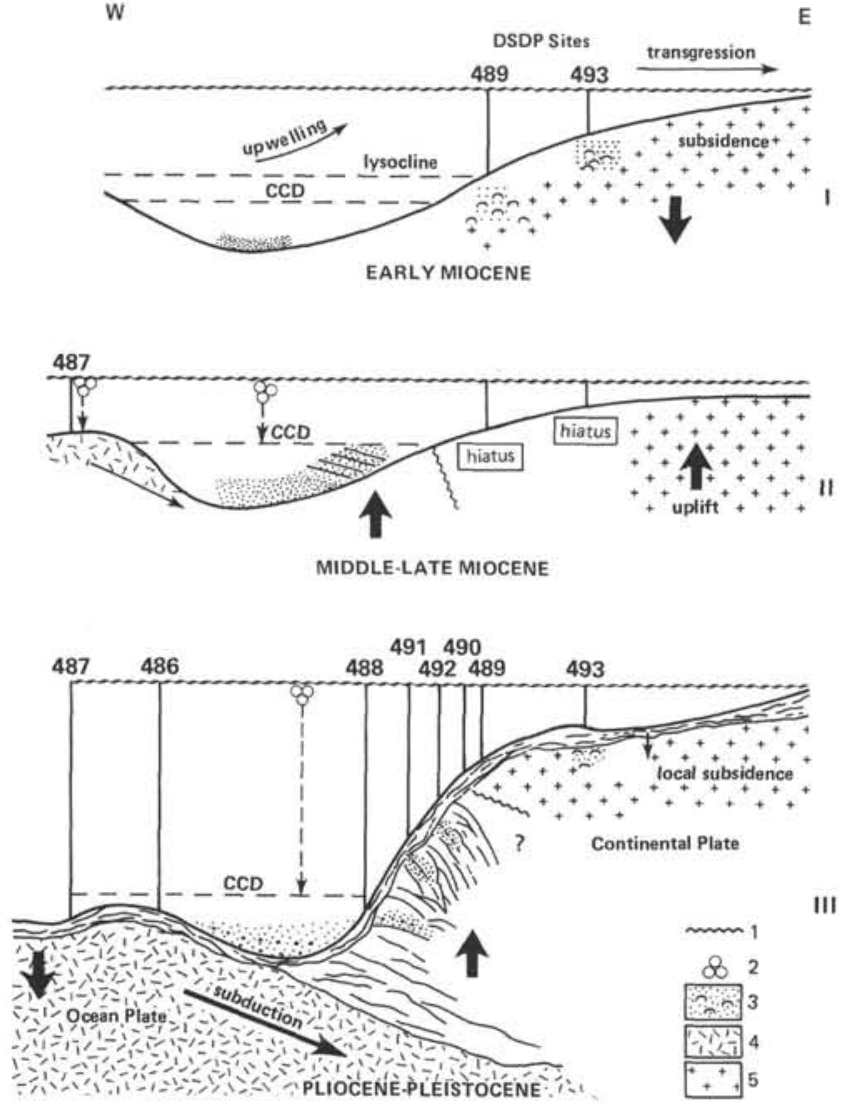

Figure 5. Schematic geologic history of the Middle America Trench during the Neogene. Three stages show syndepositional tectonics and bathymetric evolution. I: early Miocene subsidence and transgression, II: middle and late Miocene and early Pliocene uplift relative to the CCD, III: upper Pliocene to Quaternary uplift and local isostatic adjustments along the upper slope $(1=$ truncation, 2 = pelagic sedimentation, $3=$ sand with shells, $4=$ ocean crust, and $5=$ continental crust).

consist of greenish gray muddy silt facies with occasional glauconite-rich thin beds and, in the basal part, interbedded sand. In Hole 492 the foraminifers are abundant and well preserved in Cores 1 and 2, poorly preserved in Cores 3 to 5 , and very rare in Cores 6 and 7 . Well-preserved Quaternary planktonic foraminifers include Globorotalia menardii, G. tumida, G. fimbriata, Globigerinoides ruber, G. sacculifer, Globigerina bulloides, G. falconensis, Neogloboquadrina dutertrei, and Pulleniatina obliquiloculata. Cores 3 to 4 contain some Pliocene species such as Globorotalia plesiotumida, Neogloboquadrina acostaensis, Neogloboquadrina humerosa, and Globigerinoides extremus. Absence and/or poor preservation of planktonic foraminifers in the Miocene to lower Pliocene (Cores 5-31) indicate deposition below the CCD, whereas lack of benthic foraminifers indicates unfavorable living conditions at the seafloor, such as high sedimentation rate and low oxygen, although rarely reworked shallow water benthics are also encountered. In Cores 3 to 4, upper Pliocene sediment contains relative common and partially preserved planktonic foraminifers, suggesting deposition near the CCD or below the foraminiferal lysocline. The Quater- nary planktonic foraminifers in Cores 1 and 2 are excellently preserved. They indicate deposition above the CCD. Quaternary benthic foraminifers indicate a lower bathyal assemblage. Some typical representatives are Planulina wuellerstorfi, Melonis pompilioides, Hoelgundina elegans (very large specimens), Oridorsalis unbonatus, Gyroidina soldanii, Sphaeroidina bulloides, Uvigerina hispida, and Laticarinina (large specimens). The assemblage corresponds to the present-day water depth. The Miocene to Pliocene barren portion suggests that the sediments were deposited in the trench environments at a depth of 4000 to 5000 meters below the CCD, that during the late Pliocene the site was uplifted, and that during the Quaternary the accreted sediments were raised well above the $C C D$ to their present depth. The rate of uplift averages between 400 and $200 \mathrm{~m} / \mathrm{m}$.y. (Figs. 4 and 5).

Site 490 is located in the transitional zone at a water depth of 1760 meters (midslope) (Figs. 1 and 2). The sedimentary section is 588 meters thick and represents a late Miocene to Quaternary hemipelagic facies (Fig. 3). The cores display gray muddy silts, olive green to olive black in the upper part. The upper part also contains concentrations of glauconite. We also observed occasional bioturbation in the sediment. Cores 1 to 12 contain abundant, well-preserved upper Quaternary foraminifers; Cores 13 to 21 rare, poorly preserved lower Quaternary and Pliocene foraminifers; and Cores 29 to 64 , no foraminifers except for some reworked upper slope specimens. Scarcity of the foraminifers in the sedimentary section precludes application of foraminiferal zonation. However, abundance and preservation of foraminifers seem to be useful criteria in distinguishing different bathymetric history of the accreted sediment. Cores 1 to 16 contain Quaternary species such as Globorotalia tumida, G. flexuosa, G. menardii, Globigerinoides ruber, $G$. sacculifer, Neogloboquadrina dutertrei, Pulleniatina obliquiloculata, and Orbulina universa.

Benthic foraminifers include Melonis pompilioides, Planulina wuellerstorfi, Gyroidina soldanii, Cassidulina subglobosa, Hoeglundina elegans, Oridorsalis umbonatus, Pullenia bulloides, Uvigerina proboscidea, U. aculeata, U. hispida, Lagena stilostomella, and, occasionally, Pyrgo. The Pliocene section in Cores 17 to 30 contains the following rare species: Globigerinoides fistulosus, G. ruber, Hastigerina sp., Pulleniatina sp., and Neogloboquadrina humerosa. The assemblage also includes some shelf and upper slope reworked specimens such as Cancris, Planulina, and Bolivina. Sample 49024-1, 18-20 cm contains concentration of upper slope foraminifers such as Uvigerina that had been transported down by the turbidity currents.

Absence of foraminifers in the Miocene part of the sedimentary section suggests that Site 490 was located below the CCD during the late Miocene, perhaps at a depth greater than 4000 meters in the trench environment. But relatively abundant and partially preserved Pliocene and early Quaternary forms reveal deposition near the CCD and well-preserved and abundant late Quaternary foraminifers suggest that the deposition of the fossils occurred above the $\mathrm{CCD}$, corresponding to 
the present depth level of 1760 meters. The rate of uplift from late Miocene to Quaternary averages about 200 $\mathrm{m} / \mathrm{m}$.y., suggesting that the site was uplifted and passed through various dissolution levels such as CCD and foraminiferal lysocline (Figs. 4 and 5).

Site 489 is located on continental crust at a water depth of 1270 meters (Figs. 1 and 2). The lower Miocene to Quaternary sedimentary section consists mainly of green to light green and gray silts (Fig. 3). It encompasses an upper Miocene to Pliocene hiatus. Cores 489-1 and $489 \mathrm{~A}-1$ contain glauconitic silt and abundant, wellpreserved foraminifers; Cores 489-2 to 489-5 and 489A-1 through $489 \mathrm{~A}-31$ consist of light greenish gray siliceous silty mud and basal sandstone facies. The facies contain rare to common foraminifers. In the lower part of the sequence, foraminifers are relatively abundant, whereas several core catcher samples such as 489-3,CC; 489A2 ,CC through 489A-10,CC; 489-20; and 489-26 are barren. Planktonic foraminifers in Cores 489-1 and 489A-1 exclusive of core catcher samples indicate a late Quaternary age for the sediment. They are Globorotalia tumida, G. menardii, Globigerinoides ruber, G. sacculifer, G. trilobus, Pulleniatina obliquiloculata, and Orbulina universa. In Cores $489-2$ to $489-5$ and $489 \mathrm{~A}-1$ to 489A-23, the planktonic species indicate the late early Miocene (N5-N8). The species are Globorotalia peripheroronda, Globigerinoides subquadratus, G. trilobus, G. primordius, Globoquadrina altispira, Globigerina obesa, and $G$. venezuelana. Cores 489A-24 to 489A-31 contain the lower lower Miocene. Species include Globorotalia siakensis, G. aff. kugleri, and small specimens of the genus Globigerinoides.

At Site 489 the sandstone facies above the schistose basement marks an initial transgression during the early Miocene, whereas the middle Miocene to Pliocene hiatus indicates submarine erosion. The basal sandstone layers consist of bivalves, echinoid, and benthic foraminifers in the silty mud facies, indicating a near-shore shelf (200-300 m) environment during the early phase of transgression. In Cores 489A-31 to 489A-24 the benthic species include Assemblage I such as Quinqueloculina, Lenticulina, Nodosaria, Gavelinella, Hanzawaia bertheloti, Siphonogenerina, Unicosiphonia, and Stilostomella. The following small-sized specimens also occur: Cassidulina laevigata, Uvigerina sp. Hoeglundina, and Sphaeroidina bulloides. The assemblage is also associated with small in situ molluscs. The upper part of the lower Miocene is represented by light gray siliceous mud facies. The foraminifers represent Assemblage II. They include Dentalina, Nodosaria, Vaginulina, Hoeglundina, Melonis affinis, Oridorsalis umbonatus, Pullenia bulloides, Cassidulina subglobosa, Gyroidina, Pleurostomella, Siphonodosaria, Sphaeroidina bulloides, Uvigerina aculeata, U. peregrina, Pyrgo murrhina, and Vulvulina spinosa. These benthics may suggest 1000 to 2000 meters water depth (mid-bathyal to lower bathyal?). Occurrence of abundant diatoms and radiolarians and small-sized planktonic foraminifers may suggest upwelling along the slope region. Upwelled cold water masses may have suppressed productivity of the calcareous plankton as they did in coastal basins along the Gulf of California. The sediments in these basins contain abundant siliceous plankton and rare, poorly preserved, and small-sized calcareous pelagics. Alternatively, the siliceous facies may indicate deposition below the CCD, but this model requires displacement of Assemblage II from a shallower region and depth greater than approximately 3000 meters. The Quaternary glauconitic sediment contains Assemblage III. The members are Lenticulina (large specimens), Stilostomella, Cassidulina subglobosa, Planulina ornata, Gyroidina soldanii, Hoeglundina elegans, Uvigerina peregrina, U. proboscidea, and Pyrgo murrhina. Assemblage III corresponds to the mid-bathyal depth of 1270 meters. The middle Miocene to Pliocene hiatus may suggest a shallowing, probably related to submarine erosion and uplift at Site 489 .

Thus Assemblage I represents 100 to 300 meters shelf depth after the initial transgression at the crystalline basement; Assemblage II is associated with the siliceous mud and indicates 1000 to 2000 meters water depth, suggesting a rapid subsidence of the continental basement. The subsidence may indicate a short passive period of the margin. Uplift occurred probably at the rate of 80 to $100 \mathrm{~m} / \mathrm{m}$.y. to the present mid-bathyal depth, as also indicated by Assemblage III (Figs. 4 and 5).

Site 493 is located at the upper slope at a water depth of 675 meters (Figs. 1 and 2). In Hole 493, a 670-meter lower Miocene to Quaternary sedimentary section was recovered (Fig. 3). The section rests upon dioritic basement of Cretaceous(?) age and marks a transgressive contact. It also encompasses sedimentary hiatuses: middle Miocene, upper upper late Miocene, and uppermost Quaternary. The sedimentary section contains rare to abundant and well-preserved foraminifers. Cores 493A-1 to $493 \mathrm{~A}-3$ and 493B-1 to 493B-5 contain abundant and well-preserved Quaternary planktonic and benthic foraminifers. They include Globorotalia tumida, G. menardii, G. fimbriata, G. ungulata, Globigerinoides ruber, G. sacculifer, Neogloboquadrina dutertrei, Globigerina bulloides, G. falconensis, Orbulina universa, and Pulleniatina obliquiloculata. Cores 493B-6 to 493B-11 contain rare planktonic foraminifers, but interbedded sandy layers in these cores contain concentration of foraminifers (Cores 6 and 8). Typical representatives of the assemblage include Globorotalia tumida, G. acostaensis, Neogloboquadrina humerosa, Globigerinoides ruber, G. fistulosus, G. trilobus, Orbulina universa, and Pulleniatina obliquiloculata. The lower Pliocene to upper Miocene section in Cores 2 to 26 in Hole 493 contains very rare planktonic foraminifers. Several samples such as $439-3, \mathrm{CC}$ to $439-8, \mathrm{CC}$ and $439-15, \mathrm{CC}$ to $439-26, \mathrm{CC}$ are barren of planktonic species but contain relatively abundant benthic foraminifers (see the following). The planktonic species are not diagnostic for the stratigraphic subdivision. The species are Globigerinoides ruber and G. obliquus. Cores 27 to 55 contain rare to common planktonic foraminifers of lower Miocene age. They occur in Samples 27,CC to 28,CC, 30, 32, 34 to 38,41 to 42 , and 54 to 55 ; remaining samples contain abundant terrigenous sand and are barren. Some typical early Miocene species are Globorotalia peripheroronda, Globigerinoides trilobus, G. sicanus, G. diminutus, G. 
obliquus, Catapsydrax unicavus, Globigerina venezuelana, and Globoquadrina altispira.

The sedimentary section displays mainly light green to olive green gray silty mud of lower Pliocene to Quaternary, with occasional organogenic(?) turbidites and bioclastic layers consisting of concentrated fragments of bivalves. The basal cores above the basement contain transgressive calcarenites. They contain abundant shell fragments in the sandy matrix. The benthic foraminifers in the Miocene to Quaternary section represent four assemblages and indicate the depositional environment at Site 493. Assemblage I is associated with the transgressive calcarenites in the lower part of the lower Miocene and includes Lenticulina, Dentalina, Gavelinella, Hoeglundina elegans, Epistomina, and Unicosiphonia. The assemblage indicates a relatively deep shelf environment (100-200 m). In Assemblage II, light gray greenish silty mud from the upper part of the lower Miocene occurs. This facies is commonly bioturbated because of Chondrites. Benthic foraminifers include Hoeglundina elegans, Cibicidoides, Gyroidina cf. soldanii, Oridosalis cf. umbonatus, Uvigerina peregrina, U. aculeata, Cassidulina subglobosa, Siphonia, Vulvulina spinosa, and Stilostomella. The planktonic foraminifers are rare to common, but siliceous microfossils such as diatoms and radiolarians are common to abundant. The members of Assemblage II may indicate a mid-bathyal to upper lower bathyal environment (1000-1500 m), suggesting a rapid subsidence of the continental basement. Occurrence of abundant siliceous microfossils such as diatoms and radiolarians may suggest an ancient upwelling of the cold water masses, whereas absence and/or rare occurrence of calcareous microfossils may suggest a relative low productivity as well as a higher rate of terrigenous influx causing dilution, similar to the recent shallow coastal basin in the Gulf of California. Alternatively, the calcareous fossils were dissolved below the CCD at a depth between 3000 and 4000 meters, but this model implies displacement of the benthic foraminifers from a shallower level. Assemblage III occurs in upper Miocene through lower Pliocene dark gray to black laminated silty mud facies. Planktonic foraminifers are very rare, but benthic foraminifers are relatively abundant. Other microfossils include abundant diatoms and radiolarians. Benthic foraminifers include Uvigerina peregrina, $U$. excellens, Valvulineria inflata, Cassidulina crassa, C. laevigata, Bolivina seminuda, $B$. interjuncta, B. pacifica, Gavelinella Anomalinoides, and Angulogerina. The assemblage is also associated with very abundant fish bones and pyrite. The components of Assemblage III and the lithology suggest upper bathyal or outer shelf environment with low oxygen levels, in turn suggesting a raised oxygen minimum zone or an isolated basin with restricted circulations. In the tectonic sense, however, Assemblage III indicates uplift and shallowing of the basin during the late Miocene through Pliocene, as also suggested by the hiatuses in the sedimentary section. The uplift occurred at the rate of 80 to $100 \mathrm{~m} / \mathrm{m}$.y. Assemblage IV indicates present-day water depth of 675 meters at the upper slope and contains well-preserved abundant plank- tonic foraminifers (see the foregoing). Benthic species are also very abundant and include Cassidulina delicata, C. crassa, Bolivina seminuda, Planulina ornata, Cancris auricula, Gyroidina cushmani, Angolgerina angulosa, A. carinata, Uvigerina excellens, U. peregrina, U. jun$c e a$, and Pullenia. Although a general uplift of the continental plate occurs at the rate of 80 to $100 \mathrm{~m} / \mathrm{m}$.y., structures at the upper slope may indicate a local subsidence controlled by sediment load, compaction, as well as isostatic adjustment of the basement (Figs. 4 and 5).

\section{SYNTHESIS}

The East Pacific Rise marks the boundary between the Cocos and Pacific plates (Fig. 6). The Pacific Plate is the largest tectonic unit in the Pacific Ocean. It moves to the northwest over the Hawaiian hot spot (DSDP Leg 55) at the rate of $8 \mathrm{~cm} / y$. and is being subducted in the Japan, Aleutian, and Kuril Kamtschatka trenches. The Cocos Plate moves in a northeast direction at the same rate and subducts in the Middle America Trench. The Middle America Trench is 5000 to 6000 meters deep and consists mainly of three tectonic sub-units-namely, the oceanic plate (outer wall), the continental plate (inner wall), and an accretionary zone that has been growing rapidly since the Neogene. The trench is about $3000 \mathrm{~km}$ long and consists of a long, narrow basin. Laterally, across the continental slope, several submarine canyons transport terrigenous sand and shallow-water fossils. The slope is covered by a Quaternary blanket of variable thickness.

Biostratigraphic data indicate (Fig. 2) that the sediments (Oaxaca transect) decrease in age in the direction of the trench axis. At Sites 489 and 493, the oldest sediments drilled are lower Miocene; Sites 490 and 492 at middle and late Miocene, and Sites 491 and 488 (lower slope) are Pliocene to Pleistocene. This age progression from Miocene to Pleistocene suggests accretion. The pre-Neogene sediments are tectonically eroded and represent a truncated margin. Site 487 , on ocean crust, displays the late Miocene to Quaternary pelagic and hemipelagic facies. During the late Miocene, the site was lo-

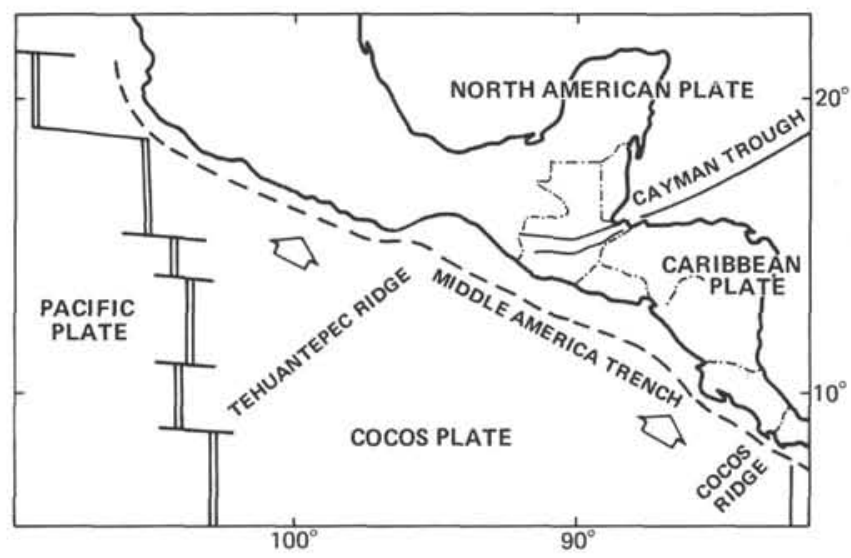

Figure 6. Plate boundaries in the southeast Pacific Ocean (after Dean and Drake, 1978). 
cated above the CCD, probably at the East Pacific Rise. Seafloor spreading, however, resulted in a landward movement of the Cocos Plate. During this movement the site subsided below the CCD, depositing mainly calcite-free brown and green clays. A change of the facies from pelagic to hemipelagic (Miocene to Quaternary) apparently suggests a proximity to the trench environments. The accretionary sites $(488,491,492)$ and the transitional zone site (490) indicate an uplift rate of 500 to $200 \mathrm{~m} / \mathrm{m} . \mathrm{y}$., whereas upper and middle slope sites (489 and 493), on continental crust, reveal 100 to 80 $\mathrm{m} / \mathrm{m}$.y. uplift. The uplift rates markedly decrease from lower slope to upper slope regions. Three lines of evidence are used to prove the uplift hypothesis. Figures 4 and 5 demonstrate the uplifting and geologic history of the Middle America Trench. They include

1) Geophysical evidence: Seismic data indicate landward-dipping reflectors along the inner wall, suggesting a general uplift of the slope areas (Shipley et al., 1979, in press).

2) Sedimentologic evidence: The inner slope sediments consist mainly of hemipelagic sediments. The sediments in the cores reveal dip angles between $20^{\circ}$ and $50^{\circ}$ Northeast; locally the dip angle varies to $90^{\circ}$ in the individual cores. Although we did not observe largescale overthrusting, small-scale deformation such as overturned folding and faulting and fracturing such as slickenslides were common. Interbedded coarse sands and pebbly mudstones in the basal parts of the accretionary zone sites and transitional zone show lithologic similarity to the recent trench fill deposits at a depth greater than 5000 meters. The ancient trench sands were uplifted following the episodes of subduction.

3) Paleontologic evidence: On the basis of abundance and preservation of planktonic foraminifers, we could distinguish three zones, $\mathrm{A}$ to $\mathrm{C}$, in all the accretionary and transitional zone sites relative to the CCD. Site 488, however, is at present located below the CCD.

\section{Zone A}

Zone A is almost barren of planktonic foraminifers, but siliceous fossils such as diatoms and radiolarians are relatively abundant. At Sites 491,492 , and 490 Zone A represents middle to late Miocene and in the basal part, early Pliocene. Absence of calcareous microfossils including planktonic foraminifers suggests that this part was deposited below the CCD at a depth between 4000 and 5000 meters. Unfortunately we did not recover in situ such abyssal benthic foraminifers as agglutinated foraminifers, below the CCD. Their occurrence could have been the most important ecologic evidence in favor of uplift hypothesis in the accretionary zone.

\section{Zone B}

Zone B contains rare and poorly preserved planktonic foraminifers, but siliceous fossils occur frequently. This zone is represented in the upper Pliocene and lowermost Quaternary sediment in the accretionary and transitional zones. It suggests that deposition of planktonic foraminifers occurred near the CCD, perhaps at a depth between 3000 and 4000 meters, which also suggests an early phase of uplift. Interestingly, this zone also contains the first occurrence of such deepwater calcareous benthic foraminifers as Melonis pompilioides. Thus Zone B may indicate a deposition at a lower slope region and reveal a progressive uplift relative to the CCD.

\section{Zone C}

Zone $\mathrm{C}$ is characterized by abundant and well-preserved planktonic as well as benthic foraminifers and indicates middle to late Quaternary age for the sediments. They correspond more or less to the present-day water depth of the accretionary and transitional zones. Zone $\mathrm{C}$ indicates a recent phase of uplift. Deposition of the calcareous fossils took place well above the CCD. General results on the accretionary zone, are shown in Figure 7.

Sites 489 and 493, at continental basement, mark an early Miocene transgression with a shelf depth of 100 to 300 meters. During the late part of the early Miocene, however, the sites subsided from mid-bathyal to lower bathyal environments, but during the middle Miocene to Quaternary, uplift occurred to the present-day water

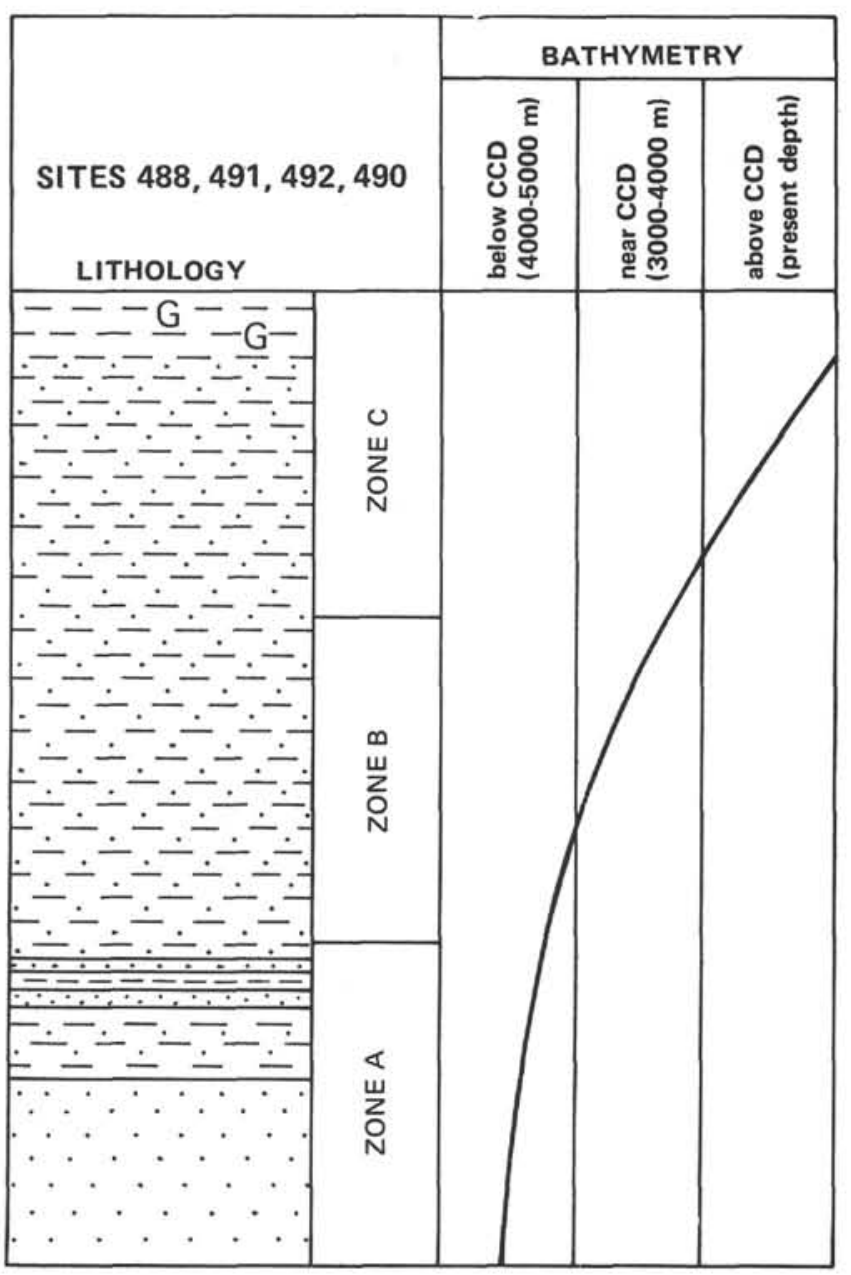

Figure 7. Generalized lithology of the accretionary zone sites showing the uplift from the zonal facies $\mathrm{A}$ through $\mathrm{C}$, discussed under synthesis. 
depth, as also indicated by benthic foraminiferal associations. However, structures such as local basins and ridges discovered through seismic data at the upper slope suggest local subsidence along the margin of the continent plate (isostatic movements). This subsidence may also indicate a new initial phase of formation of forearc basin. Figure 8 is a graphic presentation of the history of the Middle America continental margin. It illustrates syndepositional tectonic setting in the East Pacific Ocean. The uplift concept of the continental plate (see the foregoing) possibly related to the underplating is tentative. Alternatively, the hiatuses at Sites 489 and 493 may represent submarine erosion and nondeposition. The diatom-rich early Miocene mud facies, however, may simply indicate a paleoupwelling event along the truncated margin.

\section{ACKNOWLEDGMENTS}

I am thankful to the Deep Sea Drilling Project for inviting me to participate on Leg 66. Financial aid came from Deutsche Forschungsgemeinschaft (IPOD). Drs. H.-P. Luterbacher and J. Wiedmann provided research facilities at the Tübingen Institute. The manuscript was typed by Beate Döttling. I am also thankful to Dr. W. Berggren for reviewing my manuscript. All the assistance is highly appreciated.

\section{REFERENCES}

Alvarez, M., Jr., 1949. Unidades tectonicas de la Republica Mexicana. Bol. Soc. Geol. Mex., 14:1-22.

Dean, B. W., and Drake, C. L., 1978. Focal mechanism solutions and the tectonics of the Middle America Arc. J. Geol., 86:111-128.

de Cserna, Z., 1965. Reconocimiento geologico en la Sierra Madre del Sur de Mexico, entre Chilpaningo y Acapulco, Estado de Guerrero. Bol. Inst. Geol. Univ. Nac. Auton. Mex., 62:76.

Guzman, E. J., 1950. Geologia del noreste de Guerrero. Bol. Asoc. Mex. Geol. Pet., 2:95-156.

Larson, R. L., and Chase, C. G., 1970. Relative velocities of the Pacific, North American, and Cocos Plates in the Middle America region. Earth Planet. Sci. Lett., 7:425-428.

Molnar, P., and Sykes, L. R., 1969. Tectonics of the Caribbean and Middle America regions from focal mechanisms and seismicity. Geol. Soc. Am. Bull., 80:1639-1684.

Schilt, F. S., and Truchan, M., 1976. Plate motions in the northern part of the Cocos Plate. Trans. Am. Geophys. Union, 57:333.

Shipley, T. H., Houston, J. H., Buffler, R. T., et al., 1979. Seismic reflection evidence for the widespread occurrence of possible gashydrate horizons on continental slopes and rises. Am. Assoc. Pet. Geol. Bull., 63:2204-2213.

Shipley, T. H., McMillen, K. J., Watkins, J. S., et al., in press. Continental margin of Guerrero and Oaxaca, Mexico. Mar. Geol.

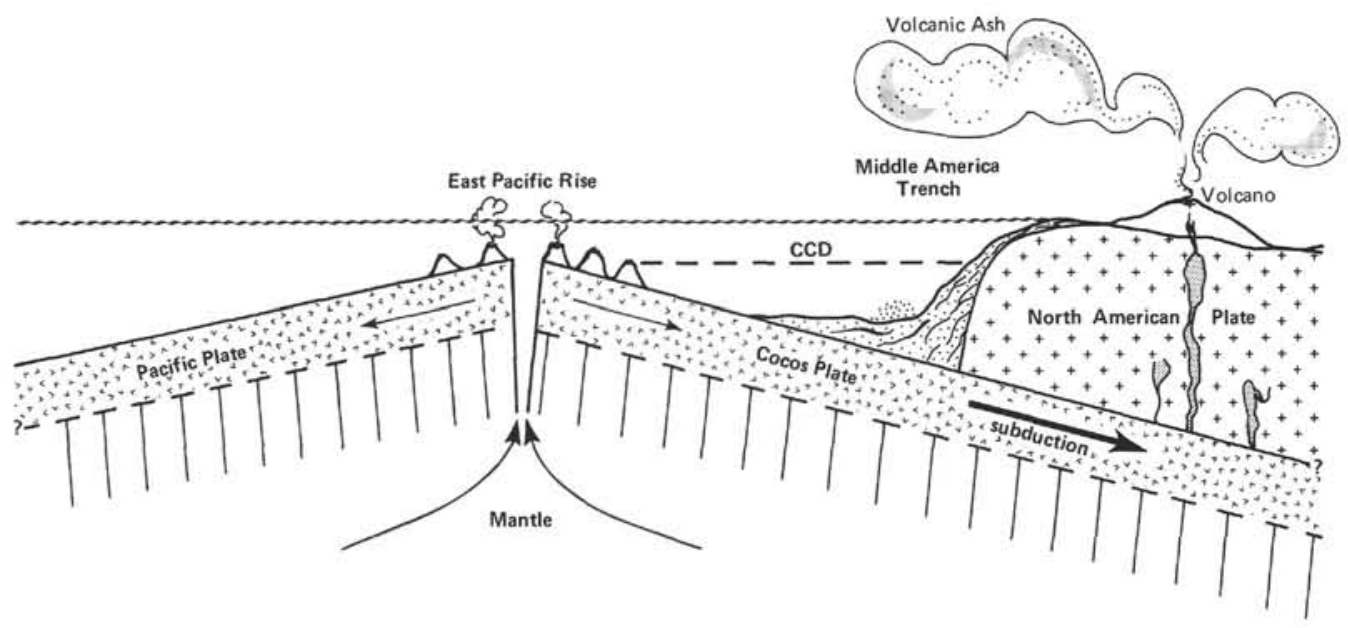

Figure 8. A schematic tectonic framework of the southeast Pacific Ocean (not to scale). 